\title{
Erratum to: Airborne bacterial diversity from the low atmosphere of Greater Mexico City
}

\author{
Jaime García-Mena $^{1} \cdot$ Selvasankar Murugesan ${ }^{1}$ • Ashael Alfredo Pérez-Muñoz ${ }^{1}$. \\ Matilde García-Espitia $^{2}$ - Otoniel Maya ${ }^{1}$ - Monserrat Jacinto-Montiel ${ }^{1}$. \\ Giselle Monsalvo-Ponce ${ }^{1}$ - Alberto Piña-Escobedo ${ }^{1} \cdot$ Lilianha Domínguez-Malfavón $^{1}$. \\ Marlenne Gómez-Ramírez ${ }^{1,3}$ • Elsa Cervantes-Gonzáles ${ }^{1,4}$. \\ María Teresa Núñez-Cardona ${ }^{5}$
}

Published online: 4 August 2017

(C) Springer Science+Business Media, LLC 2017

\section{Erratum to: Microb Ecol (2016)}

Doi:10.1007/s00248-016-0747-3

The original published version of this article has some imprecisions in the coordinates for the forward and reverse primers in $16 \mathrm{~S}$ rDNA molecule, "16S rDNA Libraries" of the "Materials and Methods" section (Page no. 76). The correct version is presented below:

The seven forward primers used in this work, V3-341F2, V3341F4, V3-341F7, V3-341F8, V3-341F9, V3-341F18, and V3-341F49 (complementary to positions 340-356), and reverse V3-518R primer (complementary to positions 517533) have already been reported [42].

The online version of the original article can be found at http://dx.doi.org/ 10.1007/s00248-016-0747-3

Jaime García-Mena

jgmena@cinvestav.mx

1 Departamento de Genética y Biología Molecular, Centro de Investigación y de Estudios Avanzados del IPN, Unidad Zacatenco. Av. Instituto Politécnico Nacional 2508, México, DF 07360, México

2 Escuela Nacional de Medicina y Homeopatía del IPN, Guillermo Massieu Helguera 239, México DF 07320, México

3 Present address: CICATA-Querétaro, Cerro Blanco 141, Colinas del Cimatario, Querétaro 76090, México

4 Present address: Departamento de Ingeniería Química, Universidad Autónoma de San Luis Potosí, Matehuala 78700, México

5 Departamento El Hombre y su Ambiente, Universidad Autónoma Metropolitana-Xochimilco, Calzada del Hueso 1100, México DF 04960, México 